- FINANSE I PRAWO FINANSOWE.

- Journal of Finance and Financial Law

Wrzesień/September 2020 • vol. 3(27): 141-154

http://dx.doi.org/10.18778/2391-6478.3.27.08

\title{
HOW ARE BANKS DOING ON SUSTAINABLE FINANCE?
}

\author{
Marika Świeszczak \\ Katedra Bankowości, Instytut Finansów, Wydział Ekonomiczno-Socjologiczny, \\ Uniwersytet Łódzki \\ ORCID: https://orcid.org/0000-0002-8813-4489
}

\begin{abstract}
In recent years, the banking sector has started to prioritize sustainable development, recognizing the growing benefits of sustainable investment. However, they e ncounter many obstacles on the road, among others, the time horizon, waiting for regulatory proposals, and a lack of understanding of the potential effects of climate change. To strengthen its sustainability policy, the ESMA decided to harmonize transparency rules that should have a significant impact on the entire banking sector.

The purpose of the article is to organize basic definitions related to the sustainable development policy, to show the role of finance in the whole process, to present important changes in the regulation, and to approximate current changes in the field of sustainable development in the banking sector.
\end{abstract}

Keywords: banking sector, sustainable finance, sustainable development, ESG, ESMA.

JEL Class: Q01. 


\section{INTRODUCTION}

In recent years, many public and private organizations have started to prioritize sustainable development. Banks are also beginning to see sustainable development as a priority. Many banking leaders are wondering how to make investment more sustainable, recognize the social impact of the industry on the circular economy, and create common good value rather than for shareholders and/or stakeholders, as is currently the case.

The current serious problem is the lack of consensus on indicators to be used to measure sustainable development practices in financial services. There are also many ambiguities (such as the lack of specific definitions) in the field of sustainable development terminology that hinder a sustainable development policy in the banking sector.

However, important changes are taking place in the area of regulation - the European Securities and Markets Authority (ESMA) has decided to include issues related to sustainable financing, including ESG (Environmental, Social, Governance) issues, in the priorities of its supervisory activities for 2020-2021. The European Banking Authority (EBA) published its action plan on sustainable finance, outlining its approach to environmental, social, and governance (ESG) factors. Based on the literature and an EBA survey, it has been shown to what extent banks are implementing a sustainable development policy in their activities, what difficulties they encounter, and what the best practices in this area are.

The purpose of this paper is to present and systematize basic definitions related to the sustainable development policy, to show the role of finance in the whole process, to present important changes in the regulation, and to present current changes in the field of sustainable development in the banking sector.

The article provides an extensive literature review and analysis of secondary ECB data in order to verify the research hypothesis: recent changes in legal regulations help banks to pursue an effective sustainable development policy.

\section{SUSTAINABLE FINANCE, GREEN FINANCE, CLIMATE FINANCE - WHAT KIND OF FINANCE CREATES SUSTAINABLE DEVELOPMENT}

Sustainable development concentrates on three aspects: economic, social, and environmental. Each of them refers to serious problems that can destabilize the world economy. The environmental aspect concentrates on problems such as climate change, land-use change, biodiversity loss, and the depletion of natural resources. The social aspect concentrates on poverty, hunger, lack of health care, disease, education gaps, social inequalities, crime, civilization diseases, underpayment, child labor, and human rights violations. The economic aspects concentrate on economic crises, unemployment, infrastructure problems, 
unsustainable industrialization, non-innovative economy, and deficits in the research and development sector [Schoenmaker and Schramade 2019: 4]. The premise of a sustainable development policy is to provide current and future generations with the resources they need, such as water, food, health care, and energy. However, a necessary condition to achieve this is avoiding stressing the Earth system [Raworth 2017: 33].

It is crucial to understand the connection between sustainable development and sustainable finance. It is said that finance should be allocated to those enterprises that invest in sustainable development, especially a low-carbon, circular economy. In other words, sustainable finance concentrates on investments that are especially important to economic, social, and environmental issues. In addition, investors (who focus on loans as well as investments) can influence the goals of companies (by achieving sustainable goals instead of the usual ones), but above all, affect the application of sustainable business practices in the enterprise. To sum it up, it is worth quoting Levine's functions of the financial system:

- It provides information on potential investment directions and capital allocation,

- After obtaining financing, it controls investments and the implementation of corporate governance,

- It simplifies the investment process and diversification in risk management,

- It accumulates savings and support investments,

- It participates in purchase and sale transactions [Levine 2005: 865-934].

Finances available for investment in banks define their lending strategies regarding which projects are too risky, and they also help choose those that are most profitable. It can, therefore, be said that the financial sector plays a key role in implementing a sustainable development policy. This is possible by focusing on sustainable companies and projects and also on directing cash resources at them [Caldecott et al. 2014: 3-19].

The financial sector is clearly transforming under the influence of the trend of financing greening in other sectors. We can find confirmation of this thesis in the words of Dziawgo: ,The financial market has been involved in supporting the pro-ecological transformation of society and the economy and, at the same time, it has been evolving slightly towards 'greening' the financial market" [Dziawgo 2014: 9-23]. The concept of green markets mentioned in this definition includes carbon finance, green stimulus funds, microfinancing, green bonds, international and national climate funds, green infrastructure, real estate funds, and socially responsible equity funds. The sustainability transition is transforming the economy towards one that is green, low carbon, resource-efficient, and that combats climate change. This transformation is supported by sustainable finance, 
green finance, and climate finance. To fully understand the difference between these concepts, it is important to note what goals they support. Sustainable finance supports sustainable development, while green finance supports the green economy, green growth, low carbon, resource efficiency. Finally, climate finance is used to adapt and mitigate climate change.

Numerous organizations and institutions have created their own definitions of green finance. For example, the G20 defines green finance as the „financing of investments that provide environmental benefits in the broader context of environmentally sustainable development" [G2O Green Finance... 2016: 3]. Another very popular definition was created by the OECD: „It can be stand-alone, a sub-set of a broader investment theme or closely related to other investment approaches such as SRI (socially responsible investing), ESG (environmental, social and governance investing), sustainable, long-term investing or similar concepts" [Inderst et al. 2014: 10]. Green finance can also be defined by specifying what it supports: green growth, the transition to the green economy, and reducing negative environmental outcomes, especially through:

- Renewable energy,

- Reducing emissions in industry,

- Sustainable transport,

- Recycling,

- Organic agriculture,

- Waste management,

- Industrial pollution control,

- Eco-innovation,

- Biodiversity protection,

- Energy efficiency,

- Water sanitation,

- Clean technology [Ryszawska 2016: 185-194].

According to $\mathrm{PwC}$, green finance for the banking sector is defined as "financial products and services, under the consideration of environmental factors throughout the lending decision making, ex-post monitoring and risk management processes, provided to promote environmentally responsible investments and stimulate low-carbon technologies, projects, industries, and businesses" [PricewaterhouseCoopers Consultants (PWC) 2013: 15].

Climate finance is one aspect of green finance that focuses on adapting to climate change or reducing or limiting greenhouse gas emissions. It is also a crucial part of global climate policy [Stewart et al. 2009: 26-28]. The United Nations Framework Convention on Climate Change (UNFCCC) does not have a definition of climate finance, but for the purposes of formulating strategies and guidelines, it was assumed that ,climate finance aims at reducing emissions, and enhancing sinks of greenhouse gases and aims at reducing vulnerability of, and 
maintaining and increasing the resilience of, human and ecological systems to negative climate change impacts" [UNFCCC Standing Committee on Finance 2014: 5]. Due to the lack of a single definition, climate finance is considered in different categories, such as:

- The source of the finance (public or private finance),

- The type of finance (microfinance, grants, loans, private equity),

- The flow mechanism of the finance (for example nationally, from „developed” countries to „developing” countries, multilaterally),

- Whether it is additional help or new support [Granthan Research Institute on Climate Change and the Environment, 2018].

The following approach to climate finance can also be found in the literature: ,[It] is generally understood as the process of enhancing the capabilities of developing countries to receive and spend climate finance wisely, as well as report on its transformative impacts" [Vandeweerd et al. 2014: 1-28; UNEP 2020; Falconer and Stadelmann 2015; PCCP 2018 Climate Change Finance...].

Sustainable finance can be defined as ,financing and related institutional and market arrangements that contribute to the achievement of strong, sustainable, balanced and inclusive growth, through supporting directly and indirectly the framework of the Sustainable Development Goals" [Sustainable Finance Study Group 2018: 8]. Another important perspective is that in the European Commission's Action Plan: ,the process of taking due account of environmental and social considerations in investment decision-making, leading to increased investments in longer-term and sustainable activities" [Sustainable Finance, 2020]. Considering this definition, the following aspects must be considered:

- Environmental considerations - they refer to all changes occurring in the environment, as well as changes occurring in the climate and ways to mitigate or overcome them,

- Social considerations - they refer to social issues such as unemployment, social exclusion, investment in human capital, and social inequalities,

- The governance of public and private institutions - the management of public and private institutions is a pillar that integrates environmental and social aspects by providing conditions for decision-making processes and activities of all entities.

What is more, all these three components are integral parts of sustainable economic development and finance.

In summary, all presented kinds of finance facilitate sustainability transition and create a sustainable financial system (Picture 1). 


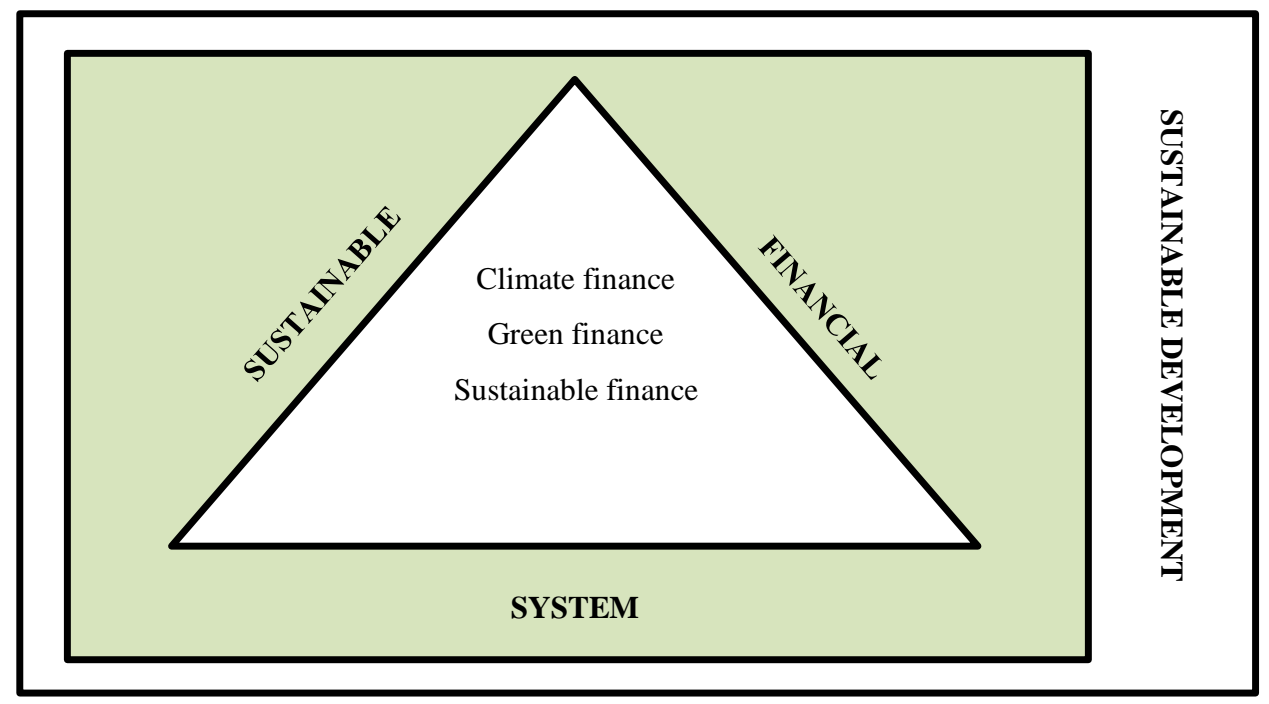

Picture 1. Finance in Sustainable Development

Source: Author's own elaboration based on UNEP, 2015: 1.

The framework for sustainable finance has changed over the last few decades. The main modification includes the departure from short-term profit towards long-term value creation [Whiteman et al. 2013: 307-336]. In the short term, sustainable finance focused on stakeholder value, and financial value was more important than the impact on both society and the environment. In the medium term, sustainable finance focused on shareholder value, and the total value is the sum of financial value, social impact, and environmental impact. In the long term, sustainable finance focused on common good value, and financial value was less important than the impact on both society and the environment (Table 1). To implement sustainable development, it is crucial to understand that shareholder value and maximizing profits must be only the beginning of further changes. The first step may be to avoid investing in non-organic ventures [Dyllick and Muff 2016: 156-174], but some companies go straight to the next level and incorporate social and environmental aspects [True Price, Deloitte, EY and PwC 2014: 21 -29]. But the real milestone is the move from risk to opportunity. We can observe two options here: avoiding unsustainable investments from a risk perspective or focusing on projects that create value for the wider community (sustainable finance leaders) [Schoenmaker 2017: 39]. Finance is designed to contribute to sustainable development, not to maximize profits. It should not be forgotten that the implemented project must be profitable, and thus achieve a fair financial return 
(the minimum level is the return on invested capital); otherwise, the projects would risk losing financial liquidity.

At the core of sustainable financing is the theory of legality, according to which enterprises try to legitimize their corporate activities in order to get society's approval and thus their further development. The result is that it is society that defines the limits and standards of socially responsible business operations [Omran and Ramdhony 2015: 38-55].

Table 1. A framework for sustainable finance

\begin{tabular}{|c|c|c|c|}
\hline $\begin{array}{c}\text { Level of sustainable } \\
\text { finances }\end{array}$ & Value created & Ranking of factors & Horizon \\
\hline I & Shareholder value & $\begin{array}{l}\text { Financial value was } \\
\text { more important than } \\
\text { the impact on both } \\
\text { society and the } \\
\text { environment }\end{array}$ & Short term \\
\hline II & Stakeholder value & $\begin{array}{l}\text { The total value is the } \\
\text { sum of financial value, } \\
\text { social impact, and } \\
\text { environmental impact }\end{array}$ & Medium term \\
\hline III & Common good value & $\begin{array}{l}\text { Financial value was } \\
\text { less important than the } \\
\text { impact on both society } \\
\text { and the environment }\end{array}$ & Long term \\
\hline
\end{tabular}

Source: own study based on: Schoenmaker 2017.

\section{ESMA ACTION PLAN ON SUSTAINABLE FINANCE}

The European Securities and Markets Authority (ESMA) has decided to include issues related to sustainable financing, including ESG (Environmental, Social, Governance) issues, in the priorities of its supervisory activities for 2020-2021. The ESMA has identified the most important priorities for sustainable financing:

- Reorient capital flows towards sustainable investment in order to achieve sustainable and inclusive growth,

- Manage financial risks stemming from climate change, resource depletion, environmental degradation, and social issues,

- Foster transparency and long-termism in financial and economic activity [EBA 2019: 5].

In the Action Plan, these aims translate into the following actions:

- Establishing an EU classification system for sustainable activities,

- Creating standards and labels for green financial products,

- Fostering investment in sustainable projects, 
- Incorporating sustainability when providing financial advice,

- Developing sustainability benchmarks,

- Better integrating sustainability in ratings and market research,

- Clarifying institutional investors' and asset managers' duties,

- Incorporating sustainability in prudential requirements,

- Strengthening sustainability disclosure and accounting rule-making,

- Fostering sustainable corporate governance and attenuating short-termism in capital markets [European Commission 2018: 4-11].

The incorporation of a sustainable development policy into corporate strategies impacts risk, return, and investment value, which has resulted in the ESMA increasing investor protection and stabilizing financial markets. This means that the ESMA will have to take into account sustainability factors throughout its entire range of activities. In particular, the ESMA will [Bacia 2020]:

- Include ESG factors in the Single Rulebook,

- Harmonize the approach of national supervisors to the risks of sustainable development under its supervisory convergence powers,

- Implement sustainable development policy in the day-to-day supervisory activities of credit rating agencies, and soon, also administrators of key EU benchmarks,

- Monitor and assess market development, including in the context of the risks associated with implementing sustainable projects, and supports stress testing and scenario analysis

The ESMA has taken into account sustainable development by harmonizing transparency principles. Completing the regulatory framework for transparency obligations will be the ESMA's key priority for 2020.

As part of ensuring supervisory convergence, the ESMA plans to eliminate regulatory arbitrage and distortions of competition that result from various supervisory practices. The ESMA's key priority in 2020-2021 will be to create a unified approach to supervisory issues, taking into account ESG factors in the practice of national supervisory authorities.

An important change will also be the imposition of the obligation to properly reduce ESG risk at the level of business processes and risk management (not only in the area of reporting) on supervised entities.

The implementation of the Guidelines on disclosure information on credit ratings will be a key priority for direct supervision in 2020. The guidelines require greater transparency from credit rating agencies as to whether ESG factors are a key factor in changing credit ratings.

The ESMA does not assess investment trends in ESG risk but plans to develop a comprehensive analytical framework, including tools and indicators, at the EU level. The most important issues considered in the research will be: an analysis of ESG factors, the financial risk resulting from climate change, and transition costs. 
The analytical framework will cover the following areas: green bonds, social bonds, emission allowances, ESG investment fund rating, stress tests related to climate risk, and market efficiency in making sustainable investments [ESMA 2020: 6-7].

\title{
3. SUSTAINABLE DEVELOPMENT AND SUSTAINABLE FINANCE IN BANKS
}

The issues of sustainable development concern not only enterprises but also banks, where one can notice more and more transformations resulting from pressure from customers, investors, and regulators. Sustainable development policies are increasingly being implemented by incorporating ESG factors into risk management models and a management framework [Alexander and Fisher 2019: 7-34].

An important issue is whether sustainable development is embedded in the business strategies of banks and what the reasons for this are. Based on the EBA survey, it can be seen that almost all institutions in the survey incorporate sustainability into their business strategies (Picture 2).

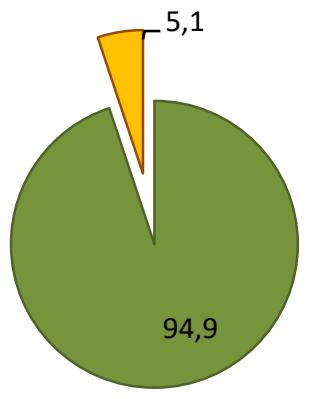

\author{
$\square$ Sustainability is \\ incorporated into banks' \\ business strategy \\ $\square$ Sustainability is not \\ incorporated into banks' \\ business strategy
}

Picture 2. Percentage of institutions with sustainability incorporated into their business strategies [in \%]

Source: Strategy on Sustainable Finance, 2020: 11.

Another important question is how the strategy on sustainability is embedded across global business objectives. The survey responses concerned the following strategies:

- Participation in creating external networks that are focused on sustainable development,

- Including ESG factors in the strategy,

- Publishing a policy statement,

- Public support for sustainable development, 
- Staff training and consideration of ESG factors in personnel management policies,

- Disclosure following TCFD recommendation.

These results show that for most institutions, the inclusion of sustainable development in business goals remained at the level of corporate social responsibility (CSR). In the survey, banks gave a few examples of their strategy on sustainability:

- The development of products such as green bonds and loans (Green finance),

- Linking a part of general management's variable remuneration to qualitative targets, including CSR targets,

- Engagement with stakeholders to promote the contribution of the financial industry to sustainable development,

- Assessing the creditworthiness of business entities taking into account impact on society and the environment,

- Developing indicators to measure the potential effects of implementing ESG policy in clients' business operations,

- Developing sectoral policies in economic sectors with a high impact on the environment,

- A privilege for borrowers who implement a sustainable development policy,

- Involvement in the development and endorsement of the UN Principles for Responsible Banking.

Furthermore, the survey shows that a number of banks consider sustainability as part of their broader business strategy, and also treat climate risk as part of financial risk. As indicated in Picture 3 below, 77 per cent of banks surveyed indicated that they do consider the direct and indirect impact of ESG policy on their business. What is more, some of them have implemented special procedures for environmental and social risks to minimize potential negative direct and indirect impacts.

The report shows that banks are positive about sustainable development policies, but obstacles still exist (Picture 4). Many banks said that the implementation of sustainable development has many challenges, and the most frequently mentioned are the time horizon, waiting for regulatory proposals, and a lack of understanding of the potential effects of climate change. Referring to this first category, it is worth emphasizing that climate risk is difficult to estimate due to its extent, probability, predicted nature and dependence on short-term activities, and whether it has an uncertain time horizon. If the investors' time horizon is shorter than the actual horizon in which the transition is expected, then the risk of transition may be underestimated. 


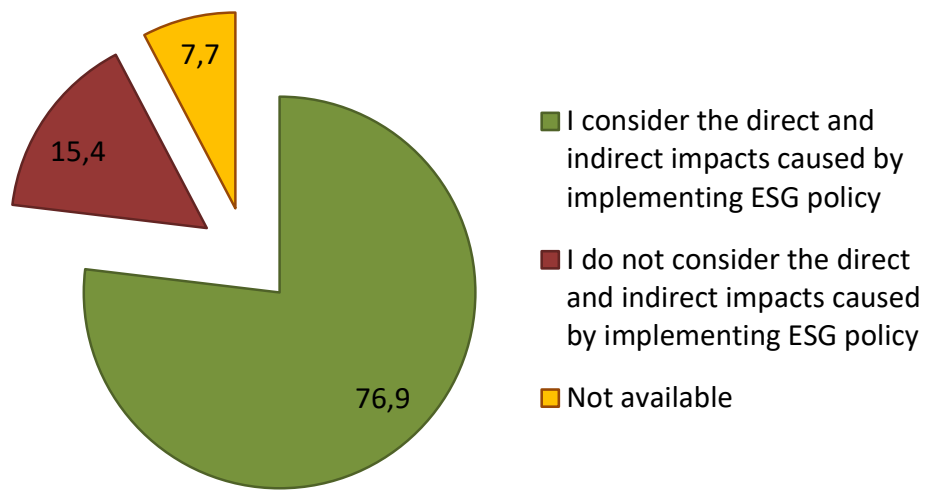

Picture 3. Direct and indirect impacts of institutions' financed activities [in \%]

Source: Strategy on Sustainable Finance, 2020: 14.

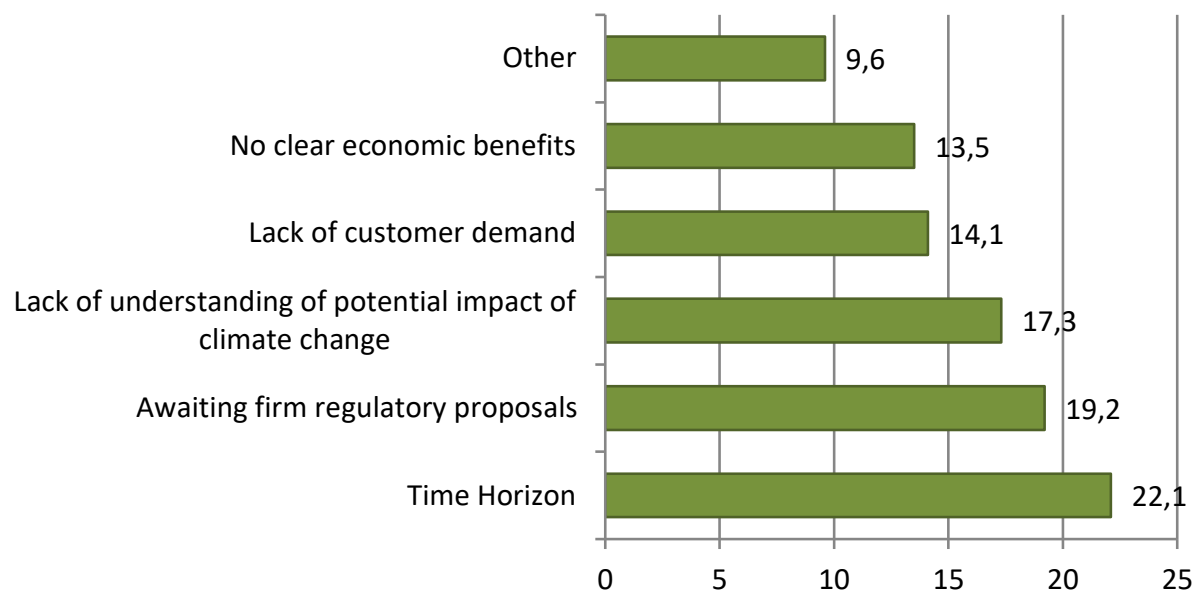

Picture 4. Main challenges to implementing sustainability [in \%]

Source: Strategy on Sustainable Finance, 2020: 15.

The second problem is the lack of unambiguous definitions in the context of the entire sustainable development policy, and then banks conducting a sustainable development policy only in accordance with the regulations (not exceeding the required minimum). It is worth adding that the global ESG regulations (Picture 5) are rising, but banks must go even further. 
To implement a sustainable development policy and make the most of its opportunities, banks should switch to long-term investments with active ownership.

A milestone would also be to move away from thinking about the distinction between sustainable and unsustainable investments in order to find new sustainable business models.

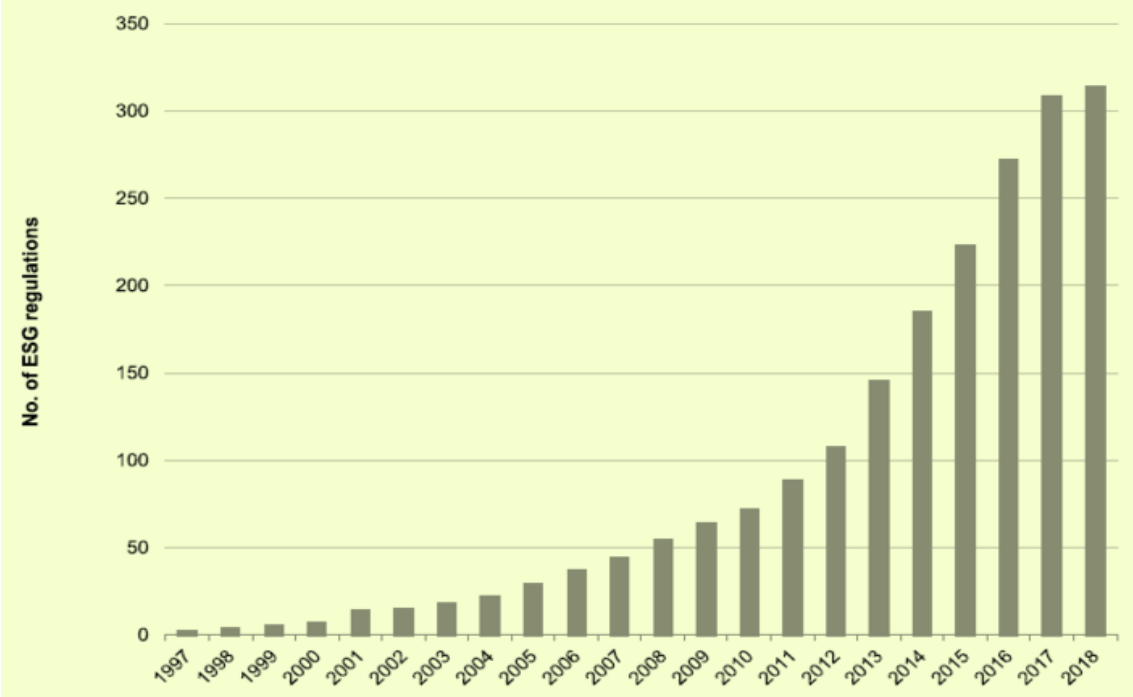

Picture 5. The number of global ESG Regulations

Source: UN Principles for..., 2019: 6.

Most banks do not fully implement the TCFD recommendations. However, a positive aspect is that almost half of them disclose information about climate change-related risks and opportunities. Based on the survey, the EBA staff research, and the TCFD recommendations, the best practices in implementing sustainable development policy include:

- Linking part of the variable remuneration of general management to ESG targets,

- Implementing appropriate organizational solutions in the field of ESG,

- Developing (or incorporating into existing) ESG strategies,

- Developing ESG risk management principles,

- Developing ESG risk indicators and/or the level of involvement in initiatives in the ESG,

- Taking action to increase involvement in the ESG [Nowakowski 2020]. 


\section{CONCLUSIONS}

The issues of sustainable development concern not only enterprises but also banks, where one can notice more and more transformations resulting from pressure from customers, investors, and regulators. Sustainable development policies are increasingly being implemented by incorporating ESG factors into risk management models and a management framework [Alexander and Fisher, 2019: 7-34].

\section{BIBLIOGRAPHY}

Alexander S.K., Fisher P., 2019, Banking regulation and sustainability, https://ssrn.com/abstract=3299351 orhttp://dx.doi.org/10.2139/ssrn.3299351.

Bacia B., 2020, ESMA przyjęła strategię w sprawie zrównoważonego finansowania, https://alebank.pl/zielone-finanse-mimo-ryzyka-banki-nie-majaalternatywy $/$ ?id $=312228 \&$ catid $=27735 \&$ cat $2 \mathrm{id}=625 \&$ cat $3 \mathrm{id}=361$.

Caldecott B.L., Tilbury J., Carey C., 2014, Stranded Assets and Scenarios, Discussion Paper, Smith School of Enterprise and the Environment, University of Oxford, Oxford.

Dyllick T., Muff K., 2016, Clarifying the meaning of sustainable business introducing a typology from business-as-usual to true business sustainability, „Organization \& Environment”, vol. 29(2), pp. 156-174.

Dziawgo L., 2014, Greening financial market, „Copernican Journal of Finance \& Accounting”, vol. 3(2), http://dx.doi.org/10.12775/CJFA.2014.014.

EBA, 2019, Action Plan on Sustainable Finance, https://eba.europa.eu/sites/default/documents/files/document_library//EBA\%20Action\%20pl an\%20on\%20sustainable\%20finance.pdf.

ESMA, Strategy on Sustainable Finance, 2020, https://www.esma.europa.eu/sites/default/files/library/esma22-1051052_sustainable_finance_strategy.pdf [access 17.01.2020].

European Commission, 2018, Action Plan: Financing Sustainable Growth, COM (2018) 97 final (8 March 2018), pp. 4-11.

Falconer A., Stadelmann M., 2015, Five Ways to Build Effective Climate Finance Readiness Programs, https://climatepolicyinitiative.org/2015/10/06/five-ways-to-build-effectiveclimate-finance-readiness-programs/ [access 17.01.2020].

G20 Green Finance Study Group 2016 G20 Green Finance Synthesis Report, 2016, http://unepinquiry.org/wp-content/uploads/2016/09/Synthesis_Report_Full_EN.pdf [access 17.01.2020].

Granthan Research Institute on Climate Change and the Environment, 2018, What is climate finance?, http://www.lse.ac.uk/GranthamInstitute/faqs/what-is-climate-finance-and-wherewill-it-come-from/ [access 17.01.2020].

Inderst G., Kaminker Ch., Stewart F., 2014, Defining and Measuring Green Investments: Implications for Institutional Investors Asset Allocations, „OECD Working Papers on Finance, Insurance and Private Pensions", vol. 24, https://www.oecd.org/finance/WP_24_Defining_and_Measuring_Green_Investments.pdf.

Levine R., 2005, Finance and Growth: Theory, Mechanisms and Evidence, [in:] P. Aghion, S.N. Durlauf (eds), Handbook of Economic Growth, Elsevier. 
Nowakowski M., 2020, Zielone finanse: mimo ryzyka banki nie maja alternatywy, https://alebank.pl/zielone-finanse-mimo-ryzyka-banki-nie-majaalternatywy/?id $=312228 \&$ catid $=27735 \&$ cat $2 \mathrm{id}=625 \&$ cat $3 \mathrm{id}=361$ [access 17.01 .2020 ].

Omran M., Ramdhony D., 2015, Theoretical Perspectives on Corporate Social Responsibility Disclosure: A Critical Review, „International Journal of Accounting and Financial Reporting” vol. 5(2), pp. 38-55.

PCCP, 2018, Climate Change Finance Readiness for the Pacific, https://www.pacificclimatechange.net/project/climate-change-finance-readiness-pacific [access 17.01.2020].

Pricewaterhouse Coopers Consultants (PWC), 2013, Exploring Green Finance Incentives in China, PWC.

Raworth K., 2017, Doughnut Economics: Seven Ways to Think Like a 21st-Century Economist, Random House Business Books, London.

Ryszawska B., 2016, Sustainability Transition Needs Sustainable Finance, „Copernican Journal of Finance \& Accounting", vol. 5(1), pp. 185-194.

Schoenmaker D., 2019, Investing for the Common Good: A Sustainable Finance Framework, https://bruegel.org/wp-content/uploads/2017/07/From-traditional-to-sustainablefinance_ONLINE.pdf [access 17.01.2020].

Schoenmaker D., Schramade W., 2017, Principles of Sustainable Finance, Oxford University Press, https://www.researchgate.net/publication/330359025_Principles_of_Sustainable_Finance [access 17.01.2020].

Stewart R., Kingsbury B., Rudyk B., 2009, Climate Finance: Regulatory and Funding Strategies for Climate Change and Global Development, NYU Press, New York.

Strategy on Sustainable Finance, 2020, https://eba.europa.eu/sites/default/documents/files/document_library/Sustainable\%20finance \%20Market\%20practices.pdf [access 17.01.2020].

Sustainable Finance Study Group, 2018, Synthesis Report, http://www.g20.utoronto.ca/2018/g20_sustainable_finance_synthesis_report.pdf [access 17.01.2020].

Sustainable Finance, 2020, https://ec.europa.eu/info/business-economy-euro/banking-andfinance/sustainable-finance_en [access 17.01.2020].

True Price, Deloitte, EY and PwC, 2014, The Business Case for True Pricing: Why you will benefit from measuring, monetizing and improving your impact, Second edition, Amsterdam.

UN Principles for Responsible Investment, 2019, ESG Database, Standard\&Poor's Financial Services LLC.

UNEP, 2015, Aligning the financial system with Sustainable Development. The Coming Financial Climate, The Inquiry`s 4th Progress Report, United Nations Environment Programme.

UNEP, 2020, What Is Climate Finance Readiness?, http://www.gcfreadinessprogramme.org/whatclimate-finance-readiness [access 17.01.2020].

UNFCCC Standing Committee on Finance, 2014, Biennial Assessment and Overview of Climate Finance Flows Report, https://unfccc.int/files/cooperation_and_support/financial_mechanism/standing_committee/a pplication/pdf/2014_biennial_assessment_and_overview_of_climate_finance_flows_report_ web.pdf p. 5 [access 17.01.2020].

Vandeweerd V., Glemarec Y., Billett S., 2014, Readiness for Climate Finance: A Framework for Understanding What It Means to Be Ready to Use Climate Finance; United Nations Development Programme, New York NY, USA, pp. 1-28.

Whiteman G., Walker B., Perego P., 2013, Planetary Boundaries: Ecological Foundations for Corporate Sustainability, „Journal of Management Studies”, vol. 50(2), pp. 307-336. 